\title{
Prinsip dan Asas Bimbingan Konseling
}

\author{
Siti Raminah \\ Email:sitiraminah2016@gmail.com \\ Universitas Negeri Padang
}

\begin{abstract}
Abstrak : Artikel ini membahas tentang Prinsip dan Asas Bimbingan dan Konseling dalam menjalankan program layanan individu. Berdasarkan pembahasan prinsip dan asas Bimbingan dan Konseling adalah pedoman dan arahan yang harus dilakukan oleh konseli kepada individu.Prinsip ini akan memberikan dampak positif untuk menunjang keberhasilan dalam program konseling.Program yang diberikan akan fleksibel serta membuat individu rileks.Individu akan memberikan pemikiran yang berbeda dan unik itulah tugas konseli untuk membantu individu dalam mengenal dirinya.Prinsip ini juga menjelasakan bahwa orang yang memberikan layanan harus kompeten dan berpendidikan yang sesuai.Prinsip BK juga terarah sesuai dengan sasaran yang diinginkan. dengan asas adalah hukum dasar dalam menjalankan layanan bimbingan dan konseling.Layanan yang berdasarkan asas akan membantu konselor dan individu untuk bergerak secara teratur dan patuh terhadap peraturan.Asas ini diharapkan dapat membantu individu dalam mengambil sikap terhadap persoalan.Asas-asas tersebut meliputi asas Kerahasiaan,Keterbukaan,Kesukarelaan,Kegiatan,Kemandirian,Kekinian,Kedinamisan,Keterpadu an,Kenormatifan,Keahlian,Alih Tangan dan Asas Tut Wuri Handayani.Asas tersebut akan menuntun individu dalam menjalankan program layananan Bimbingan dan Konseling
\end{abstract}

Kata Kunci:Prinsip,Asas,BK,Layanan

Abstract : This article discusses the Principles and Principles of Guidance and Counseling in running individual service programs. Based on the discussion of the principles and principles of Guidance and Counseling is a guideline and direction that must be done by counsellors to individuals. This principle will have a positive impact to support the success in the counseling program. The program will be flexible as well as relax the individual. Individuals will give different and unique thoughts that is the task of the counsellor to help the individual in getting to know himself. This principle also makes it clear that the person providing the service must be competent and educated accordingly.BK principle is also directed in accordance with the desired target. with the principle is the basic law in carrying out guidance and counseling services.Basic services will help counselors and individuals to move regularly and comply with regulations. This principle is expected to assist individuals in taking a stand on the issue. These principles include the principles of Confidentiality, Openness, Volunteerism, Activities, Self-Reliance, Contemporary, Dynamism, Harmony, Normality, Expertise, Hand-Over and Tut Wuri Handayani Principles.The principle will guide individuals in carrying out guidance and counseling service programs

Keywords:Principles, Principles, BK, Services 


\section{A. Pendahuluan}

Cara berfikir dan kemampuan individu berbeda-beda.Banyak factor yang menjadikan pemikiran itu berbeda,baik dari diri sendiri maupun lingkungan.Keberagaman yang terjadi menjadi tolak ukur kemampuan individu dalam berfikir.Setiap permasalahan akan diselesaikan dengan pemikiran dan cara yang berbeda,tergantung individunya.Penyelesaian masalah walaupun cara yang ditempuh berbeda tetapi pada dasarnya sama.Itulah tugas dari layanan bimbingan dan konseling dalam memberikan arahan yang bisa ditangkap oleh individu sesuai kalangan dan factor lingkungannya.Dalam perkembangan layanan BK,konselor akan memberikan pemahaman dasar untuk semua kalangan sehingga mereka bisa menuangkan pemikiran dan kemampuan terhadap permasalahan yang ada.

Adapun dalam dunia pendidikan,bimbingan dan konseling menjadi upaya untuk mencapai standard pendidikan yang telah ditetapkan.Layanan pendidikan akan membantu individu dalam menemukan jati diri untuk masa depan.Setiap individu akan mendapatkan layanan yang optimal guna membangun kemampuan diri dalam mengambil suatu keputusan.Keputusan yang diambil harus bisa dipertanggungjawabkan sebab akibatnya nanti,barulah individu bisa merancang apa yang sebaiknya dilakukan untuk mengurangi kesalahan yang terjadi nantinya.

Dalam dunia pendidikan bimbingan dan konseling digunakan untuk memberikan layanan pendidikan yang tepat agar individu bisa menerima atau memahami suatu persolan sesuai dengan kemampuannya.Pendidikan yang diperoleh menjadi dasar dalam mencapai kemauan dalam masa depan.Integrasi pendidikan yang baik akan membawa individu ke arah yang tepat dan efisien sesuai dengan kemampuannya.Bimbingan dan Konseling akan memberikan integrasi visual dimana pembimbing akan memberikan gambaran yang tepat ketika mengambil suatu keputusan.Gambaran tersebut akan membawa perubahan pola pikir individu dalam mengambil keputusan yang akan dipertanggung jawabkan nanti.

Bimbingan dan Konseling juga akan membantu dalam perkembangan diri baik dalam lingkungan keluarga,kelompok dan lingkungan sosial.Potensi yang diberikan akan membantu individu dalam menjalankan peran sesuai situasi dan kondisi.Pembimbing senantiasa mendorong individu dalam berfikir logis untuk analisis persoalan dengan pemikiran yang tepat.Pemikiran yang logis akan menghasilkan keterpaduan hasil sesuai potensi yang dimiliki.

Layanan BK juga bukan hanya untuk permasalahan pribadi dan pendidikan saja.BK juga akan membimbing dalam pemilihan keorganisasian yang cocok sesuai kemampuan diri.Layanan bk akan menuntun kelebihan dan kekurangan yang akan didapati dari setiap organisasi.Kebanyakan individu akan lebih senang atau terbuka dalam menjalankan organisi,sebab disana mereka akan mengeluarkan kemampuan diri dan terasa bebas dalam berekpresi.Organisasi juga akan menambah teman,menambah kemampuan diri untuk bersikap terbuka untuk berhubungan sosial.Disana akan didapatkan kepuasan diri dalam kemampuan bekerja sama dan bertanggung jawab atas keputusan yang diambil.

Dalam melakukan Layanan Bimbingan dan Konseling harus dengan kemauan diri sendiri,bukan paksaan dari orang lain.Kemauan tersebut akan memicu keberhasilan bimbingan dalam mengembangkan potensi diri.Potensi itu akan muncul sesuai keinginan diri dalam mengembangkannya,persoalan yang diberikan akan membantu muncul potensi intelegensi diri.Proses layanan diharapkan membawa keterbukaan diri dalam melakukan bimbingan.Keterbukaan dalam mengeluarkan pemikiran yang menggangu diri dalam menjalankan aktivitas.Orang yang melayani harus dari ahli dan telah dipastikan pendidikannya,bukan sembarang orang yang memberikan konseli.Layanan yang diberikan juga 
diharapkan dalam memberikan rasa nyaman dan aman.Ketegangan akan membuat kegagalan dalam layanan,sifat takut terbuka tidak akan bisa diberikan program yang sesuai.Kesalahan program disebabkan oleh tidak nyaman sehingga banyak hal yang ditutupi membuat konseli ragu untuk memberikan layanan yang baik.Layanan akan berusaha membuat rasa aman agar individu tetap melakukan bimbingan agar terjadi pembukaan pemikiran secara jujur dan logis guna membantu perkembangan diri.

Dalam hal tersebut,bimbingan dan konseling membutuhkan langkah-langkah yang baik untuk menuntun individu dalam melakukan kehidupannya.Individu akan diberikan layanan sesuai dengan yang dibutuhkan.Layanan yang diberikan BK membutuhkan prinsip supaya tercapai dan berjalan baik dalam melakukan pelayanan.Layanan akan berperan dalam mengatasi persoalan nyaman dan aman agar proses konseli bisa berjalan sesuai dengan program yang diberikan.Untuk itu bimbingan dan konseling membutuhkan asas yang mengatur semua ketakutan dalam mengeluarkan pemikiran tersebut agar terjalin rasa aman nyaman dalam proses layanan.Prinsip dan Asas tersebut akan menjadi pedoman atau jalan untuk menajamkan keberhasilan saat melakukan layanan.Prinsip dan asas tersebut juga dilakukan sesuai dengan kegunaanya atau kebutuhan dalam individu untuk mengambil atau menuntun keputusan.Untuk itu artikel ini akan menjelsakaan prinsip dan asas Bimbingan dan Konseling dalam melakukan layanan.

\section{B. Pembahasan}

\section{Pengertian Prinsip dan Asas}

Prinsip berasal dari kata prinsipira artinya permulaan untuk menghasilkan karya baru,dimana keberadaanya akan menentukan hal tersebut yang dibungkan secara teoritik dan teori lapangan dalam menajalankan pedoman yang diinginkan ( Halaen,2002;63 ).

Prinsip Bimbingan dan Konseling berarti aturan main yang dilakukan dalam mengambil peran untuk pelayanan BK.Prinsip ini akan menjadi landasan dalam program pelaksanaan bimbingan agar lebih terarah dan teratur.Landasan dalam langkah awal memberikan program yang sesuai terhadap kemampuan pola fikir serta kemampuan psikologis dalam individu.

Asas merupakan suatu tumpuan atau titik acuan dasar dalam berfikir atau berpendapat.Asas menjadi dasar dalam hukum dasar layanan Bimbingan dan Konseling.Secara umum asas adalah sumber dasar hukum dalam menjalankan suatu hubungan dengan orang lain sesuai norma dan ketentuan yang berlaku.Dalam Bimbingan dan Konseling,asas dimaksudkan menjadi dasar hukum dalam melakukan layanan bimbingan.Dasar tersebut mejadi hal yang harus dijalankan agar tercapai keberhasilan dalam program layanan.

\section{Prinsip Bimbingan dan Konseling}

\section{a) Prinsip berkaitan dengan Sasaran Layanan}

Saran layanan yang dimaksud adalah individu dalam perkembangan dan kehidupannya dipengaruhi oleh sikap dan tingkah laku dengan aspek-aspek lingkungan diri yang memicu pedoman dalam melakukan program layanan BK.Prinsip-prinsip tersebut yaitu:

- BK melayani semua individu,tanpa memandang umur,warna kulit,kenis kelamin,agama,status dan sosial ekonomi

- BK akan berurusan dengan tingkah laku yang unik dan dinamis

- BK akan memperhatikan perkembangan individu

- BK akan memperhatian perbedaan individual yang akan menjadi pedoman dalam melakukan layananya.

b) Prinsip berkaitan dengan Masalah Individu 
Permasalahan individu baik positif dan negative akan mempengaruhi perkembangan kemampuan berfikir.Setiap permasalahan yang dihadapi akan membuat individu terbiasa dalam mengambil sikap cepat dan tepat.Akan tetapi kemampuan setiap individu berbeda,jadi untuk itu diperlukan prinsip yang sesuai agar layanan tepat sasaran.Prinsip tersebut yaitu:

- BK akan berhubungan dengan pengaruh mental dan fisik individu dalam lingkungan rumah dan lingkungan sekitar serta sosial ekonomi dan sebalinya pengaruh lingkungan terhadap tingkah individu tersebut.

- Perhatian utama BK mengarah pada kesenjangan sosial ekonomi sera kebudayaan dalam pengaruh sikap dan tingkah laku individu.

\section{c) Prinsip berkaitan dengan program Layanan}

Prinsip dalam layanan BK,yaitu:

- BK adalah bagian dari proses pendidikan dan perkembangan,untuk itu BK akan dipadukan dengan pendidikan dalam proses perkembangan

- Program BK akn fleksibel sesuai kebutuhan individu

- Program akan disusun sesuai jenjang pendidikan,mulai dari terendah sampai tertinggi.

\section{d) Prinsip berkaitan dengan Pelaksanaan Layanan}

Pelaksanaan layanan yang baik adalah fleksibel,dimana akan sesuai dengan kebutuhan individu.Pelayanan akan terprogram untuk mencapai keputusan dari individu.Pelayanan akan memenuhi tujuan layanan BK dalam menggali kemampuan berfikir serta psikilogis individu.Prinsip tersebut yaitu:

- BK akan mengarahkan untuk perkembangan individu sehingga bisa mengambil keputusan dalam permasalahan.

- Keputusan yang diambil harus dari diri sendiri bukan paksaan dari orang lain

- Permasalahan yang dihadapi harus sesuai dengan bidang yang relevan

- Kerja sama antar guru dan orangtua untuk mencapai keberhasilan layanan

- Pemgembangan program BK melalui pemamfaatan dari pengukuran nilai terhadap individu dalam proses pelayanan dan program bimbingan dan konseling (Hanen,2002).

Prinsip Bimbigan dan Konseling tercantum dalam lampiran Pemendibud no.111 Tahun 2014 Tentang Bimbingan dan Konseling Pada Pendidikan Dasar dan Pendidika Menengah.Terdapat 12 prinsip yang harus dipegang oleh guru bk atau konselor,yaitu:

1) Bimbingan dan Konseling untuk semua peserta didik dan konseli tidak deskriminatif.Prinsip ini dimana setiap individu akan menerima bimbingan secara menyeluruh oleh konseli dengan adil dan sesuai dengan programnya.

2) BK sebagai proses individuasi,maksudnya individu berbeda dan unik serta dinamis sehingga dibutuhkan konseli dalam membantu pembentukan diri.

3) BK menekankan nilai positif,maksudnya konseli akan memberikan nilai positif terhadap semua permasalahan yang akan dicari solusinya.

4) Bimbingan dan konseling adalah tanggung jawab bersama,maksudnya semua ikut berperan dalam melaksanakan peran bk dilingkungan sekolah

5) Pengambilan keputusan adalah hal esensial dalam BK,maksudnya BK akan memberikan arahan dalam mengambil keputusan untuk menyelesaikan persoalan individu.

6) BK berlangsung disemua situs kehidupan,bukan hanya lingkungan konseli tetapi keluarga,masyarakat,lingkungan pendidikan dan bangsa negara. 
7) BK merupakan integral layanan pendidikan karena itu akan mencapai tujuan pendidikan nasional

8) BK dilaksalanakan dalam lingkungan budaya Indonesia.Intergrasi guru dan siswa harus selaras dengan budaya yang ada.

9) BK bersifat fleksibel dan adiftif serta berkelanjutan dengan memperthatikan sarana dan prasanan mendukung

10) BK dilaksanakan oleh tangan yang kompeten seperti guru BK atau konselor yang akademik sarjana pendidikan dalam Bimbingan dan Konseling serta telah lulus dalam Pendidikan Profesi Konselor dari Lembaga Pendidikan Tinggi Kependidikan

11) Program bimbingan harus sesuai dengan kebutuhan individu dalam aspek perkembangan

12) Program tersebut harus dievaluasi untuk melihat keberhasilan layanan dan pengembangan program lebih lanjut.

Dari prinsip diatas sudah jelas bahwa dalam melakukan layanan,konseli tidak deskriminatif dan adil terhadap semua individu.Konseli juga akan membantu dalam menemukan solusi yang tepat,tetapi bukan berarti konseli yang mengambil keputusan melainkan individu itu sendiri.Konseli hanya akan menuntun untuk mencapai pemikiran dalam mencapai solusi permasalahan.Dalam pelayanan BK juga dibutuhkan peran dari semua kalangan,agar proses program yang diberikan dapat terjamin dengan baik dan berkelanjutan.Program yang diberikan juga sesuai dengan permasalahan individu.Individu sendiri sangat unik dan dinamis,mereka harus dibimbing untuk memahami diri sendiri agar mengetahui keingian diri untuk masa depan.

Prinsip Bimbingan dan Konseling akan dijadikan pedoman dalam melakukan layanan program kepada individu sebagai sumber dari terjalinnya proses layanan.Layanan diberikan oleh orang yang sudah kompeten dan terjamin pendidikannya.BK juga akan memberikan dampak positif dalam pemikiran yang matang,dimana BK akan mengajak berfikir secara luas dan menggunakan perasaan sebab akibat dalam mengambil keputusan.BK akan mengajak untuk rileks dan fleksibel dalam proses layanan.

\section{Asas Bimbingan dan Konseling}

\section{1) Asas Kerahasiaan}

Asas ini berhubungan dengan rahasia klien atau individu bersifat data atau persoalan yang dihadapi.Dalam hal ini pembimbing akan menjaga rahasia dari data individu terhadap orang lain dan menjamin rasa aman terhadap pandangan buruk dari orang lain.Biasanya semua data disimpan ditempat khusus dan hanya dapat diakses oleh pembimbing tersebut.

\section{2) Asas Kesukarelaan}

Asas yang menghendaki individu dalam melakukan layanan Bimbingan dan Konseling dengan kesukarelaan dalam menjalankan program yang diberikan.Dalam hal ini konselor akan mengembangkan kesukarelaan tersebut sehingga individu dapat mengeluarkan pemikirannya dalam persoalan yang sedang dihadapi.

\section{3) Asas Keterbukaan}

Asas ini diharapkan kepada individu untuk bersikap terbuka dan tidak berpura-pura baik dalam data diri maupun persoalan yang akan diberikan layanan,agar program yang diberikan oleh konselor tepat sasaran.Dalam hal ini konselor akan mengembangkan sikap terbuka dan menerima lapang dada hal yang akan dikeluarkan.Hal tersebut juga akan 
membantu asas kerahasian untuk kelancaran dalam penyelenggaraan program layanan Bimbingan dan Konseling.

\section{4) Asas Kegiatan}

Asas ini menghendaki individu ikut aktif dan berpartisipasi dalam program layanan yang diberikan bimbingan.Dalam hal ini konselor akan mengikutsertakan individu dalam program tersebut,jika tidak ikut serta maka program yang dijalankan tidak akan berhasil.Sebab program tersebut berguna untuk menyelesaikan persoalan individu bukan konselor.

\section{5) Asas Kemandirian}

Sesuai dengan tujuan umum dari Layanan Bimbingan dan Konseling dimana individu akan bersikap mandiri dalam menghadapi persoalan baik dalam diri sendiri maupun lingkungan sekitar.Untuk itu diharapkan dalam layanan ini tercipta individu yang bersikap mandiri tinggi agar tidak bergantung kepada orang lain yang membuat individu seperti pengecut dan manja.

\section{6) Asas Kekinian}

Dimana asas ini diharapkan layanan yang diberikan konselor terkait dengan persoalan sekarang atau masa kini untuk bisa diberikan gambaran masa lalu dan masa datang sesuai situasi dan kondisinya.Gambaran masa depan itu akan berpengaruh terhadap keputusan yang diambil masa kini,untuk itu layanan yang diberikan bisa membantu individu menyelesaikan persoalan sekarang secara matang agar tidak berpengaruh terhadap masa depan.

\section{7) Asas Kedinamisan}

Asas ini diharapkan indvidu dalam menerima layanan Bimbingan dan Konseling bergerak maju dan tidak monoton.Isi yang diharapkan tetap berkembang selama proses layanan berlangsung agar mencapai sifat mandiri dan matang dalam mengambil keputusan dengan tanggung jawab yang tepat.Dalam hal ini konseli akan memantau perkembangan individu dalam mengatasi persoalan yang dihadapi.

\section{8) Asas Keterpaduan}

Asas ini diharapkan individu dalam menerima layanan Bimbingan dan Konseling baik dari guru atau orang lain bisa diterima secara terpadu.Dalam hal ini keterkaitan atau keikutsertaan dari pihak lain dalam proses layanan akan membantu individu lebih bisa mengontrol diri dan siap menghadapi persoalan lain dengan pemikiran yang logis dan efisien.

\section{9) Asas Kenormatifan}

Asas Bimbingan dan Konseling dalam memberikan layanan diharapkan tidak bertentangan dengan nilai dan norma yang berlaku,yaitu norma hukum,agama,adat istiadat,ilmu pengetahuan,dan kebiasaan yang berlaku.Bimbingan dan Konseling terjadi bukan hanya hasil tetapi proses dalam mendapati hasil tersebut sesuai dengan peraturan yang berlaku.Layanan yang diberikan seharusnya akan membantu individu untuk meningkatkan nilai dan norma agar tidak hilang dan dibantah oleh kalangan.

\section{0)Asas Keahlian}

Asas Bimbingan dan Konseling diharapkan dalam memberikan layanan harus ditangani oleh orang yang professional.Dalam hal ini layanan yang diberikan oleh tenaga yang benar ahli dalam bidangnya,bukan sembarang orang.Keahlian guru harus bisa dibenarkan dalam memberikan layanan sesuai dengan kaidah dan prinsip agar tidak terjadi hal yang melenceng.Ahli akan memberikan layanan sesuai dengan kode etik dan peraturan yang berlaku serta dengan pengalaman dalam melakukan bimbingan.

\section{1) Asas Alih Tangan}

Asas ini berhubungan jika konselor dalam menyelesaikan layanan Bimbingan dan Konselig terhadap individu tidak menemukan titik temu maka konselor harus mengalihkan ke 
tangan yang lebih ahli dan berpengalaman.Guru bisa mengalih tangan kepada keluarga atau konselor lain dengan memberikan gambaran persoalan individu supaya konselor baru bisa memahami dan mempersiapkan program layanan yang diharapkan mampu menemukan titik temu persoalan individu.

\section{2)Asas Tut Wuri Handayani}

Asas Bimbingan dan Konseling dalam memberikan layanan diharapkan dapat mengayomi,memberikan rasa aman dan nyaman,megembangkan keteladanan,memberikan rangsangan dan kesempatan yang luas kepada individu untuk bergerak maju.Dalam hal ini konselor akan memberikan kesempatan terhadap gambaran pemikiran individu untuk melakukan sesuatu sesuai dengan kehendak tetapi masih dalam batas wajar.

Bimbingan dan Konseling akan memberikan layanan tepat guna dan bermanfaat kepada individu dalam memecahkan persoalan.Layanan tersebut akan menuntun dalam kemandirian untuk bersikap dan dewasa dalam mengambil keputusan.Layanan itu diharapkan agar individu dapat berkembang dan terus maju untuk melukis masa depan.

\section{Kesimpulan}

Prinsip Bimbingan dan Konseling adalah pedoman atau alat dalam menjalankan proses program layanan bk agar berjalan sesuai peraturan dan berdampak positif kepada individu.Prinsip ini akan memberikan dampak positif dan fleksibel dalam layanannya,dimana program yang diberikan akan sesuai dengan persolana individu.Layanan BK juga membutuhkan peran dari lingkungan sekitar agar program berhasil dilakukan dan mencapai solusi yang diharapkan.Setiap individu akan memiliki sifat yang unik dan dinamis dalam menerima suatu informasi,jadi konseli akan memberikan arahan dimana individu akan mengenal jati diri sesuai kemampuan dan cara pandangnya.Biasanya konseli akan memberikan suatu gambaran kemudian individu akan memberikan tanggapan,dari situ konseli akan mengetahui kemampuan berfikir logis dan analisisnya.Konseli akan mengetahui program yang sesuai jika individu sudah merasakan rileks dalam melakukan layanan.Prinsip yang dibutuhkan akan memberikan arahan bagaimana tindakan yang harus dilakukan konseli kepada individu.

Dalam melaksanakan layanan program,konseli juga membutuhkan peran dari kalangan sekitar untuk membantu jalannya prinsip serta mengembangkan keberhasilan program untuk dikembangkan lebih luas lagi.Prinsip dalam BK akan menuntun individu untuk bisa mengambil keputusan sendiri bukan paksaan dari orang lain.Konseli hanya akan memberikan arahan dan beberpa solusi jika terjadi kejanggalan dalam keputusan yang diambil,lalu individu itu sendiri yang akan bergerak dalam melaksanan keputusan tersebut.Disanalah peran penting prinsip BK untuk memberikan arahan yang baik kepada konseli dan kepercayaan dari individu dalam program layanan serta arahan dari orang yang berkompeten dan terjamin pendidikannya.

Bimbingan dan Konseling membantu individu dalam mencari jati diri.Layanan yang diberikan akan membantu dalam proses perkembangan pemikiran menuju kematangan dan mandiri dalam bertingkah laku dalam mengambil keputusan.Program layanan itu sesuai dengan persoalan untuk membantu mendapatkan hasil sesuai pemikiran individu terhadap langkah selanjutnya.Dalam layanan aka nada asas yang menjadi pedoman individu dan konselor untuk mencapai hasil yang diharapkan.Asas-asas tersebut akan memicu perkembangan dalam diri individu.Layanan yang diberikan diharapkan membuat individu aman dan nyaman untuk bergerak maju mengejar impian.Asas itu juga bersifat mandiri dan terbuka,dimana individu 
diharapkan dapat menjelaskan dengan rinci tanpa ditutupi persoalan sehingga dapat memicu kemandirian dalam bertindak sesuai pemikiran yang logis da efisien.

Layanan juga diharapkan dapat memberikan perkembangan bukan hanya monoton.Perkembangan dalam menggambarkan tindakan masa depan dengan acuan masa sekarang.Persoalan kekinian yang dialami individu bisa menjadi dasar dalam gambaran masa lalu dan masa depan,tentunya sesuai dengan nilai dan norma yang berlaku.Jika melakukan Bimbingan dan Konseling tidak disertai nilai dan norma maka hasil yang didapat akan mencoreng sikap individu dalam mengambil tindakan,sebab tindakan yang diambil dapat membahayakan diri sendiri dan orang yang terlibat didalamnya.Dalam memberikan layanan individu juga dilakukan oleh ahli bukan sembarang orang,jika ahli tersebut tidak bisa memberikan hasil yang memuasakan kepada individu maka bisa diahli tangankan kepada orang yang lebih ahli.Jadi,layanan Bimbingan dan Konseling akan memberikan yang terbaik dan memberikan solusi terhadap persoalan serta membantu dalam perkembangan menuju mandiri dan matang serta memberikan kesempatan yang luas kepada individu dalam menata masa depan.

\section{Daftar Pustaka}

Haryatri, H. (2019). Urgensi Bimbingan dan Konseling di Sekolah Dasar. Jurnal Al-Taujih: Bingkai Bimbingan dan Konseling Islami, 5(1), 92-102.

KURNIATI, E. (2018). BIMBINGAN DAN KONSELING DI SEKOLAH; PRINSIP DAN

ASAS. Ristekdik: Jurnal Bimbingan dan Konseling, 3(2), 54-60.

Mufrihah, A. (2014). Implikasi prinsip bimbingan dan konseling terhadap kompetensi multikultural konselor. Jurnal Pelopor Pendidikan, 7(1), 73-85. 